\title{
Training hydrologists to be ecohydrologists and play a leading role in environmental problem solving
}

\author{
M. E. McClain ${ }^{1,2}$, L. Chícharo ${ }^{3}$, N. Fohrer ${ }^{4}$, M. Gaviño Novillo ${ }^{5}$, W. Windhorst ${ }^{6}$, and M. Zalewski ${ }^{7,8}$ \\ ${ }^{1}$ Department of Water Science and Engineering, UNESCO-IHE Institute for Water Education, P.O. Box 3015, \\ 2601 DA Delft, The Netherlands \\ ${ }^{2}$ Department of Earth and Environment, Florida International University, 11200 SW 8th Street, Miami Florida 33199, USA \\ ${ }^{3}$ Universidade de Algarve, Faculty of Sciences and Technology, Campus de Gambelas, 8005-139 Faro, Portugal \\ ${ }^{4}$ Department of Hydrology and Water Resource Management, Institute for the Conservation of Natural Resources, \\ Kiel University, Kiel 24118, Germany \\ ${ }^{5}$ Facultad de Ingeniería, Universidad Nacional de la Plata, La Plata - Buenos Aires, Argentina \\ ${ }^{6}$ Department of Ecosystem Management, Institute for the Conservation of Natural Resources, Kiel University, Kiel, Germany \\ ${ }^{7}$ International Institute of Polish Academy of Sciences, European Regional Centre for Ecohydrology under the Auspices of \\ UNESCO, 3 Tylna Str., 90-364 Łódź, Poland \\ ${ }^{8}$ Department of Applied Ecology University of Lodz, 12/16 Banacha Str., 90-237 Łódź, Poland
}

Correspondence to: M. E. McClain (m.mcclain@unesco-ihe.org)

Received: 19 January 2012 - Published in Hydrol. Earth Syst. Sci. Discuss.: 1 February 2012

Revised: 29 May 2012 - Accepted: 29 May 2012 - Published: 22 June 2012

\begin{abstract}
Ecohydrology is a relatively new and rapidly growing subject area in the hydrology curriculum. It is a trans-disciplinary science derived from the larger earth systems science movement and examining mutual interactions of the hydrological cycle and ecosystems. It is also an applied science focused on problem solving and providing sound guidance to catchment-scale integrated land and water resources management. The principle spheres of ecohydrology include (i) climate-soil-vegetation-groundwater interactions at the land surface with special implications for land use, food production and climate change; (ii) riparian runoff, flooding, and flow regime dynamics in river corridors with special implications for water supply, water quality, and inland fisheries; and (iii) fluvial and groundwater inputs to lakes/reservoirs, estuaries, and coastal zones with special implications for water quality and fisheries. We propose an educational vision focused on the development of professional and personal competencies to impart a depth of scientific knowledge in the theory and practice of ecohydrology and a breadth of cross-cutting knowledge and skills to enable ecohydrologists to effectively collaborate with associated scientists and communicate results to resource managers, policy-makers, and other stakeholders. In-depth knowledge
\end{abstract}

in hydrology, ecology, and biogeochemistry is emphasized, as well as technical skills in data collection, modeling, and statistical analysis. Cross-cutting knowledge is framed in the context of integrated water resources management. Personal competencies to be fostered in educational programs include creative thinking, cooperation, communication, and leadership. We consider a life-long learning context but highlight the importance of master's level training in the professional formation of ecohydrologists.

\section{Introduction}

The water cycle plays an influential role in many earth system processes, and the study of hydrology is the means for understanding these influences. Inquiries into the nature of the water cycle date back to ancient Greece and the beginning of science itself (Nace, 1974), but the appearance of hydrology as a discipline was marked by the establishment, in 1922, of the Section of Scientific Hydrology in the International Union of Geodesy and Geophysics (Volker and Colenbrander, 2009). From the start, hydrology was recognized as an applied science with direct ties to water management and 
hydraulic engineering. Soon hydrological influences in other sciences began to appear as discrete sub disciplines. Hydrobiology appeared in the 1940s, and the very first article published in the journal Hydrobiologia addressed the problem of harmful algal blooms associated with runoff from agricultural and urban catchments (Prescott, 1948). Hydrochemistry emerged as the study of the chemical characteristics of water and was applied to phenomena ranging from rock weathering to all forms of contamination degrading water quality. Geologists had studied ground water and the relationship between water supply and geologic strata for nearly $200 \mathrm{yr}$, and in 1956 leaders in that sub discipline formed their own International Association of Hydrogeologists. The emergence of new sub disciplines thus reflects the growing body of scientific knowledge in a discipline, with natural subdivisions following new theoretical and conceptual threads, as well as a response of science to new societal needs and perceived problems.

Over the past $30 \mathrm{yr}$, our perception of the planet and its problems has changed profoundly. We are moving away from sectoral thinking and ad hoc technical interventions to a more integrated and systems view of land and water resources management (GWP, 2000). Among the most important shifts in perception driving this change have been the determination of the full extent of human impacts on the world's ecosystems (MEA, 2005; Falkenmark, 2003) and the confirmation that anthropogenic climate change is occurring (IPCC, 2007). In fact, the magnitude of human influences on ecosystems and climate has prompted the definition of a new epoch, the Anthropocene (Steffen et al., 2007). The response of the scientific community to these changes has led to the growth of a new earth systems science that blends multiple disciplines in pursuit of new and transformational understanding about the changing planet (Leemans et al., 2009). Many synergistic sub disciplines have emerged from earth system science, including ecohydrology.

Ecohydrology, as an applied science linked to environmental change and integrated water resources management, took shape in UNESCO's International Hydrology Program and Man and the Biosphere Program (Zalewski, 2000; Zalewski et al., 2008). Its theoretical foundations lie in the role of precipitation and groundwater in controlling climate-soilvegetation dynamics, the role of runoff flow regimes in regulating the ecological structure and function of aquatic ecosystems, and the role of flow pathways in regulating key biogeochemical processes and elemental cycles (Rodriguez-Iturbe, 2000; Falkenmark, 2003; Poff et al., 1997; McClain et al., 2003). As with the emergence of any new sub discipline, there has been some debate about definitions, terminology, and thematic scope (Kundzewicz, 2002; Hannah et al., 2007), but the conceptualization of ecohydrology supported by UNESCO's International Hydrology Program is transformative in its degree of integration, problem-solving focus, and policy orientation (Zalewski et al., 1997; Zalewski, 2002, 2011). The establishment of ecohydrology in the wider community is also evident in the appearance of dedicated peer-reviewed journals, an increasing number of dedicated institutes, and new university programs (Rickwood et al., 2010) (Table 1).

Education in hydrology has struggled to keep pace with rapidly expanding and changing demands brought by research advancements and new world views. This special issue on Hydrology Education in a Changing World therefore comes at an opportune time, when the hydrological community is reconsidering the future of the science and needed changes (Wagener et al., 2010). Twenty years ago a joint IAHS/UNESCO panel was convened to assess the status of education in hydrology and, based on that assessment, recommended fundamental changes in hydrological education to elevate graduates from narrow technologists to wellrounded geoscientists (Nash et al., 1990; Daugharty, 1991; Klemes, 1991). The panel called for educational programs that consolidated and developed hydrology as a coherent geoscience, recognizing the water cycle as the integrating process and considering the full spectrum of time and space scales. The disciplinary boundaries of hydrology were articulated and the broad subjects at undergraduate and graduate levels defined. The value of modeling was noted, but emphasis was placed on observation and experimentation and the need to increase field and laboratory experience in educational programs. Two additional observations of the panel we would like to highlight are the need for depth in some systematic specialization and recognition of the multidisciplinary nature of hydrology and need for hydrologists to learn to work in teams to address "major problems involving the interaction of man with the hydrological environment on the global scale" (Nash et al., 1990). A number of potential specializations were suggested, among them a specialization in hydrology and biological processes. Education in hydrology has advanced greatly over the past $20 \mathrm{yr}$, but certain of the panel's recommendations and certainly its spirit remain valid (Wagener et al., 2012).

In this paper we consider the education of ecohydrologists and outline a curriculum, professional and personal competencies, and didactic approaches. As our title suggests, we advocate for an educational approach to equip newly trained ecohydrologists with the knowledge and skills to effectively engage in, and lead, coordinated efforts to address key environmental problems. This approach is motivated by a recognized need for innovation in solving major water-related problems and for more $\mathrm{T}$-shaped young professionals who possess both depth of disciplinary knowledge (the vertical) as well as cross-cutting knowledge and personal competencies (the horizontal) that enable them to work effectively in teams (Wagener et al., 2010; Uhlenbrook and de Jong, 2012). First we outline the thematic spheres of ecohydrology as a means of introducing the essential elements of the sub discipline and then consider both professional and personal competencies recommended in the training of ecohydrologists. 
Table 1. Selection of journals, institutes, and university programs dedicated to ecohydrology. See Rickwood et al. (2010) for a more extensive list.

\begin{tabular}{l}
\hline Peer-Reviewed Journals \\
\hline Ecohydrology and Hydrobiology, (established 2001) \\
Ecohydrology, (est. 2008) \\
\hline Dedicated Centers \\
\hline UNESCO European Regional Centre for \\
Ecohydrology, Poland \\
UNESCO International Centre for Coastal \\
Ecohydrology, Portugal \\
Institute of Hydroecology, China \\
Centre of Excellence for Ecohydrology, Australia \\
Centre for Ecology and Hydrology, UK \\
Institute of Hydroecology and Ichthyology, Armenia \\
Asia Pacific Center for Ecohydrology, Indonesia \\
\hline Degree Programs \\
\hline Bachelor Degree in Ecohydrology, University of Nevada, \\
Reno (est. 2007) \\
MSc in Ecohydrology, Universidad Nacional de La Plata, \\
Argentina (est. 2004) \\
Erasmus Mundus MSc in Ecohydrology, Portugal, Poland, \\
Germany, Netherlands, Argentina (est. 2010) \\
MA in Ecohydrology, University of Lodz, Poland (est. 2010) \\
Professional Science Masters Degree in Ecohydrology \\
Science and Management, University of Idaho \\
B.S. Biological and Agricultural Engineering: Ecohydrological \\
Engineering Option \\
MSc in Hydrology, VU University Amsterdam: \\
Ecohydrology Specialization \\
MSc in Ecology, Colorado State University: \\
Ecohydrology Research Area \\
Watershed Management and Ecohydrology MSc or \\
PhD option at the University of Arizona \\
\hline
\end{tabular}

\section{The spheres of ecohydrology}

Ecohydrology is concerned with the mutual interactions of the hydrological cycle and ecosystems, with an emphasis on the provision of a wide range of ecosystem services (Fig. 1). The most ubiquitous sphere of ecohydrological processes encompasses the interactions of plants and water exchanged between the atmosphere, soil vadose zone, and groundwater (Rodriguez-Iturbe, 2000; Lange et al., 1976). The initial establishment and large-scale (time and space) occurrence of vegetation depends on climate and water availability but, on small to intermediate scales and in the absence of extreme climatic events, vegetation may exert a controlling influence on water movements and even local climate (Osborne et al., 2004). A second important sphere of ecohydrological processes lies in stream and river corridors, where terrestrial vegetation continues to exert an important influence on runoff generation, but where flow becomes the master variable controlling the structure and function of aquatic ecosystems including riverine wetlands (Poff et al., 1997). A third sphere of ecohydrological processes encompasses lakes, reservoirs, estuaries and coastal zones, where freshwater influxes and associated particulate and dissolved loads exert strong controls on ecosystem structure and function (Livingston et al., 1997). These three spheres are of course interconnected in the continuum of the hydrological cycle and include the interactions of physical, biological, and biogeochemical processes. Vibrant communities of researchers are investigating processes in each of these spheres and are offering innovative solutions to related water management challenges. In the following paragraphs we briefly highlight research activities and management implications in each sphere. These descriptions are offered as examples of content likely to be considered in ecohydrology training programs.

\subsection{Ecohydrology of the land surface: land conservation and food production}

The principal interactions of hydrology and ecology at the land surface involve the hydrologic pathways of precipitation, infiltration, and evapotranspiration. Despite sometimes controlling influences, biological processes are commonly excluded from water balance equations and represented by purely physical variables (Monteith, 1965; Priestly and Taylor, 1972). Ecohydrological research, however, acknowledges the complexity of plant-soil-water interactions at multiple scales (Pitman, 2003; Popp et al., 2009) and over heterogeneous landscapes (Caylor et al., 2006). The balance of soil moisture is central to this research and its spatiotemporal influence on ecosystem structure, productivity, and species diversity (Porporato and Rodriguez-Iturbe, 2002). Important feedbacks include vegetation control of local climate (Osborne et al., 2004) and self organization of vegetation in water limited environments by controlling infiltration rates (Rietkerk et al., 2002). Much of the focus of this sphere has been in arid and semi-arid ecosystems, where soil moisture may be the limiting factor (Nemani et al., 2003; Newman et al., 2006), but increasing attention is now being directed at humid areas (Rodriguez-Iturbe et al., 2007). For a comprehensive recent review of these topics, see Asbjornsen et al. (2011).

The environmental management implications of this sphere of ecohydrology are large, both because anthropogenic-driven land use change has altered nearly half of Earth's surface and much of the land conversion is related to food provision for a burgeoning human population (Vitousek et al., 1997; Foley et al., 2005). Changes in the composition and configuration of vegetation alter the hydrological cycle from plot to continental scales (Colman, 1953; Likens et al., 1977; Eshleman, 2004) and set in motion a cascade of related impacts, some intended and others not (Wilcox, 2010). In addition to working to better understand 


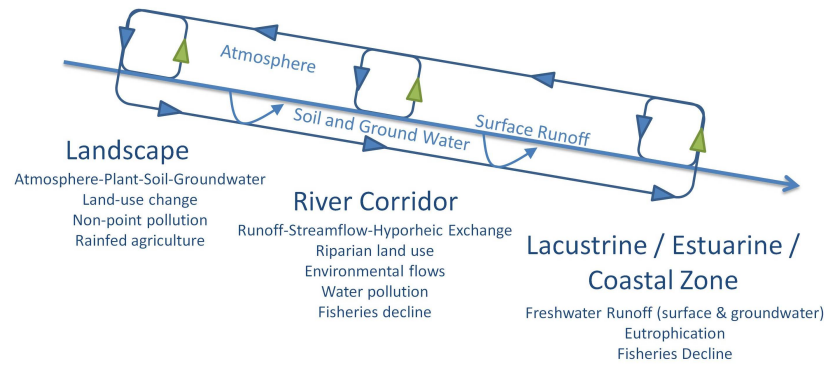

Fig. 1. Schematic representation of spheres of ecohydrology and key processes and issues highlighted in this paper. Spheres are integrated in the continuum of the hydrological cycle and considered in the context of hydrographic catchments extending from headwater landscapes to estuaries and coastal seas.

process-level changes brought by land use change, ecohydrologists are also working to develop and improve modeling tools to assess impacts over entire catchments (Fohrer et al., 2005; van Griensven et al., 2006). Ecohydrologists are certainly concerned with the conservation of natural landscapes, but the applied area in which they are likely to play the largest role is in improved food production in rainfed agriculture (Falkenmark and Rockström, 2004, 2006; Rockström et al., 2009).

\subsection{Ecohydrology of river corridors: competing uses, fragmentation, and declining water quality}

Interactions between hydrology and ecology in river corridors include those land surface processes described in the previous section as well as the full suite of interactions in flowing water ecosystems. Over the past $20 \mathrm{yr}$ ecologists have come to recognize the unique ecological value of riparian zones and wetlands as ecotones between terrestrial and aquatic ecosystems (Naiman and Decamps, 1997). The enhanced biodiversity and ecological function of these systems is attributed to extraordinary physical heterogeneity produced by variable flood regimes and geomorphic processes, altitudinal climate shifts, and influences of runoff from uplands (Naiman et al., 1993). Exchanges of surface water and groundwater within the hyporehic zone underlying streams and rivers have been found to exert important hydrological controls on stream ecology (Brunke and Gonser, 1997; Boulton et al., 2010), and together riparian, wetland and hyporheic ecohydrological processes have been found to play a controlling role in regulating nutrient fluxes from uplands throughout river basins (Wondzell, 2011). Flow regime is considered a master variable in controlling the ecology of lotic ecosystems (Poff and Allan, 1995; Poff et al., 1997; Naiman et al., 2008), and there has been increased attention devoted to the ecological response of aquatic organisms to changes in flow regime (Lytle and Poff, 2004; Poff and Zimmerman, 2010).
The ecosystem services provided by rivers and wetlands are estimated to be more valuable, per $\mathrm{km}^{2}$, than those of any other ecosystem on Earth (Costanza et al., 1997). At the same time, rivers and wetlands are the most heavily impacted by human interventions (Meybeck, 2003; Dudgeon et al., 2006; Vörösmarty et al., 2010), making them the focus of intensive ecohydrological research to guide needed management interventions. Due to the degraded state of many river corridors, restoration is a major area of research (Zedler, 2000; Tockner and Stanford, 2002; Wohl et al., 2005). Ecohydrologists are addressing the role of flow regime and hydrologic connectivity in the restoration of ecological function in river corridors (Richter et al., 1997; Bornette et al., 1998; Ward et al., 2001; Lake et al., 2007). Flows necessary to protect desired ecological functions are referred to as environmental flows and represent a key focal area of applied ecohydrological research (Arthington et al., 2010). Another focal area is applied and modeling studies of the role of natural attenuation processes in protecting and improving water quality, especially in agricultural landscapes (Dosskey, 2001; Seitzinger et al., 2002; Burgin and Hamilton, 2007; McClain, 2008) but also in urban areas (Wagner and Zalewski, 2009).

\subsection{Ecohydrology of lakes, estuaries, and coastal zones: eutrophication and fisheries}

Ecohydrology in lacustrine and coastal ecosystems has focused mainly on the ecological influences of hydrological influxes of water, particulates, and solutes from upstream catchments. This sphere of ecohydrology therefore builds upon the preceding spheres, following runoff from its source on the landscape and through river corridors. This emphasizes again a fundamental tenet of ecohydrology, which is the consideration of processes operating at a full catchment scale even if the specific unit under study is a lake or estuary (Zalewski, 2002; Wolanski et al., 2004). Influxes of water from contributing rivers and groundwater dominate the water balance inputs of most lakes (excluding the great lakes) and control the salinity profiles of most estuaries (Hill et al., 1998; Klimmerer, 2002; Robins et al., 2005). Each of these influence the spatiotemporal availability of specific habitats, which may be important during particular life stages of fauna and flora. The nutrient load of contributing inflows also exerts strong controls on primary productivity, which then affects productivity at higher trophic levels in food webs (Livingston et al., 1997; Chícharo et al., 2006; Marcarelli et al., 2011). Because many fish, shrimp, and other aquatic organisms migrate over the course of their life histories, the heightened productivity of lentic, estuarine and coastal ecosystems may be important to river corridors that benefit from the nutrient subsidies carried by migrating organisms (McDowall, 2008).

Lakes, reservoirs, estuaries, and coastal zones are areas of heightened ecosystem services, especially for fisheries and provision of food. Lakes and reservoirs are also important 
sources of freshwater. These systems are, however, especially vulnerable to alterations in freshwater inputs and contamination. The most well-known example of flow alterations is the desiccation and related environmental disaster of the Aral Sea due to diversions of the Amu Dar'ya and Syr Dar'ya rivers for irrigated agriculture since the 1960s (Micklin, 1988). Similar patterns of desiccation are affecting other lakes across arid Central Asia (Bai et al., 2011) and wetlands in Latin America (Gaviño Novillo, 2005). Alteration of freshwater inflows to estuaries is also known to reduce the productivity of fisheries and other ecological functions (Drinkwater and Frank, 1994; Gillanders and Kingsford, 2002; Gillson, 2011). An important area of ecohydrological research is thus the assessment of freshwater flow requirements for estuaries (Alber, 2002; Robins et al., 2005; Sun et al., 2008). The most ubiquitous problem in this sphere is, however, eutrophication and the myriad ecological changes and potentially severe hypoxia it may cause (Cloern, 2001; Smith, 2003; Vadeboncoeur et al., 2003). Ecohydrological research addresses the interacting hydrological, biogeochemical, and ecological processes leading to eutrophication, as well as the full suite of catchment-scale management interventions that may help reduce harmful effects (Wolanski et al., 2004).

\section{A Curriculum for Ecohydrological Education}

Addressing the complex challenges described above has required a paradigm shift in natural resources management, merging technical and sociopolitical interventions (PahlWostl et al., 2007; Zalewski, 2011). Adoption of this approach in natural resource management has been disappointingly slow, however, and in instances where it has been applied, results are often unsatisfactory. We believe that this is in part because many traditionally trained resource managers, engineers, and policy makers lack the professional and personal competencies to lead or even effectively participate in truly integrated programs. Because the full value of ecological services has been recognized only recently, this aspect of natural resources management is particularly lacking among decision makers. A number of cross-cutting educational programs spanning science and policy have emerged in recent years, and more are initiated each year. As part of this larger trend toward more integrative training in earth systems science, we offer the following view of professional and personal competencies to develop and foster in the education of ecohydrologists.

\subsection{Professional competencies}

The preceding sections illustrate the scope of ecohydrology, a sub discipline of hydrology integrated with ecology and biogeochemistry in the context of catchment-scale and coastal-zone natural resources management. Soil science, geomorphology, meteorology, and hydraulics are also important topics in one or more of its spheres. Process understanding is important across all spheres, and necessary technical skills range from plot-level to remotely-sensed data collection, monitoring design, stochastic and deterministic modeling, and statistical analysis. To achieve the problem-solving objectives of the science, ecohydrologists must understand the policy-making process and the essential interactions of social and economic factors in a resource management context (Fig. 2). The formation of ecohydrologists with this combination of knowledge and technical skills is clearly challenging and will not be accomplished in a single degree program. We therefore frame our discussion of needed professional competencies in a larger educational context.

Education is a continuum beginning in childhood and continuing during a lifetime of learning. Students begin to follow lines of specialized training at different ages in different countries. Most receive a liberal arts secondary education, and increasing numbers are now completing university degrees. All scientific professions depend on math and science education at the primary and secondary level. At the 1999 UNESCO/ICSU World Conference on Science, delegates called for a renewed commitment of nations to education in science and mathematics at all levels, but especially primary and secondary education (UNESCO/ICSU, 1999), and many countries in Europe and around the world are responding with specific initiatives (e.g. Fibonacci project in Europe and Math and Science Education Initiative in the USA).

Specialized scientific training generally begins at university level, and thus a question arises of whether ecohydrology should be distinguished as a degree or specialization at an undergraduate (e.g. BSc) or graduate (e.g. MSc) level. While interdisciplinary undergraduate degrees are becoming more common, and at least one bachelors degree in ecohydrology has already been established (Saito et al., 2009), in general we suggest that aspiring ecohydrologists focus on one of the component sciences of ecohydrology during their bachelor's studies in order to develop a depth of knowledge in one key area of greatest personal interest. Nash et al. (1990) suggested that the undergraduate education of hydrologists should focus on earth science, which is appropriate given the roots of hydrology. For future ecohydrologists, an undergraduate degree in ecology or environmental biology is also appropriate. In reality, however, ecohydrologists may come from many natural science backgrounds or from the growing assortment of interdisciplinary undergraduate degrees. Whichever the undergraduate pathway, it is important that the student be prepared in the fundamentals of mathematics, physics, chemistry, biology, geology, statistics, and the basic humanities. It is also at the undergraduate level that most students will be exposed to the basics of hypothesis formulation and testing, appropriate and careful data collection, good laboratory practices, numerical modeling, data analysis, and the 


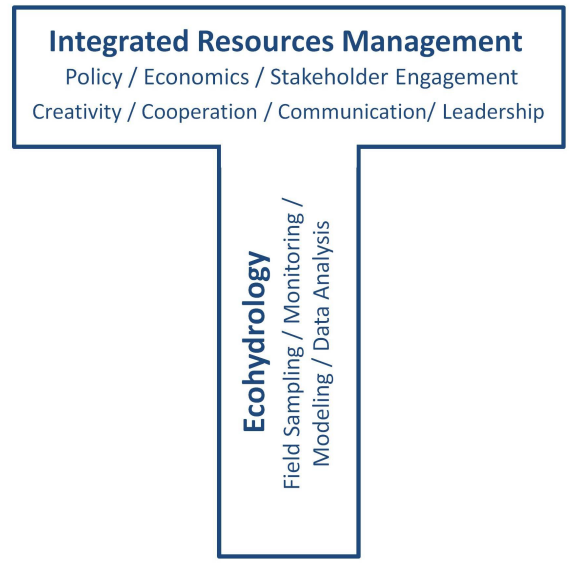

Fig. 2. T-shaped competencies of an ecohydrologist. The vertical bar reflects the depth of specialized scientific knowledge, while the horizontal bar reflects cross-cutting knowledge of related disciplines as well as personal competencies enabling more effective participation in collaborative teams.

sum of associated skills and world view that constitute the scientific ethos (Merton, 1976).

The master's degree is the level at which professional distinctions are drawn in a number of fields, and it is at this level that the education of ecohydrologists is most likely to become definitive. Students entering master's studies will have completed the full curriculum of a relevant bachelor's degree and may already have significant professional work experience. Graduate students are an integral component of university-based research programs, ideally publishing the results of their thesis research in peer-reviewed journals and participating in academic conferences and professional societies. The master's level is thus ideal for ecohydrologists to begin specializing in the interactive elements of hydrology and ecology, to more broadly explore the management and policy context, and to transition directly into a professional field where they can apply that knowledge and engage with stakeholders.

A 2-yr master's degree composed of coursework and thesis research generally allows for a maximum of 8-12 courses, which may be required or elective. Required courses should include a foundation course in ecohydrology, as well as courses in surface and groundwater (including vadose zone) hydrology, hydrological modeling, aqueous biogeochemistry, plant-water interactions (e.g. plant physiology), aquatic ecology, ecosystem restoration, environmental policy, and integrated water resources management (IWRM) (Table 2). Depending on the background of students, redundant courses can be waived and replaced by additional electives, which should be offered in a wide range of topics to allow for greater specialization. One or more statistics courses should be required, including multivariate and ideally Bayesian hierarchical approaches, which are transforming the way complex environmental data are analyzed (Ellison, 1996; Katz et al., 2002). The IWRM and environmental policy courses should include detailed content on strategic environmental assessment (SEA), stakeholder engagement, gender considerations, ecosystem valuation, and other fundamental principles of sustainable development and the role of science in achieving development goals (GWP, 2000; Cash et al., 2003). Some emphasis should also be given to methods courses that teach practical skills in the field and laboratory and computer applications like geographic information systems (GIS). Guided group work in the solution of catchmentscale water resource problems should be emphasized where possible in courses (Willis et al., 2002; Hmelo-Silver, 2004). Master's thesis research should address clearly defined questions in one of the spheres of ecohydrology. Coherency and a continuous focus on ecohydrology can be achieved throughout the program by hosting a weekly seminar series and/or organizing regular group discussions.

A small proportion of students will continue on for a research-based $\mathrm{PhD}$, which should explore advanced research questions at the forefront of ecohydrological science. Several recent collaborative initiatives have sought to define these research frontiers (Arthington et al., 2010; Wagener et al., 2010; Asbjonsen et al., 2011)

Most practicing ecohydrologists were trained in a related field and later drifted into ecohydrology because of interest or perhaps need in the case of applied scientists. These professionals, and others still to come, would benefit from a curriculum of non-degree short courses or online courses that present advancements in key areas of ecohydrology. Examples include (i) vegetation management to maximize groundwater infiltration, (ii) rainfed agricultural optimization, (iii) environmental flow assessments, (iv) catchment approaches to reduce lake and coastal eutrophication, and (v) riparian buffers.

\subsection{Personal competencies}

Our perspective on educating ecohydrologists emphasizes the applied nature of the sub discipline and the importance of direct engagement with resource managers, decision makers and other stakeholders to address pressing water resource management challenges. As we transition to a worldview in which water management seeks to better balance infrastructure with soft engineering and sustainable use of other ecosystem services (Zalewski, 2011; Palmer, 2010), we expect ecohydrology to play an increasingly important guiding role and for ecohydrologists to play leading roles in developing and implementing new and innovative solutions. For this reason, we advocate for education that does not focus solely on the professional competencies of the individual but also the personal competencies (Ngambeki et al., 2012). These include skills in creative thinking, cooperation, communication, and leadership. The terminology of "competencies" used in this paper conforms to a shift in education over recent 
Table 2. Example course list from the Erasmus Mundus Ecohydrology MSc Program (www.ecohyd.org) offered in cooperation between the University of Algarve (Portugal), University of Lodz (Poland), University of Kiel (Germany), UNESCO-IHE Institute for Water Education (The Netherlands), and National University of the Plata (Argentina). Students in this two-year MSc program take three semesters of courses in at least two of the participating institutions (plus a summer program in Argentina) and then conduct their thesis research at one these institutions or another cooperating institute. Courses with an asterisk (*) are compulsory, depending on the mobility scheme of the student. Others are elective.

\begin{tabular}{l}
\hline Core \\
\hline Ecohydrology* \\
Ecohydrology in Urban Areas* \\
Estuarine and Coastal Ecohydrology* \\
\hline Technical Knowledge and Analysis \\
\hline Hydraulics and Hydrology* \\
Environmental Hydrology* \\
Dynamics of Aquatic Ecosystems* \\
Estuarine processes and wetlands* \\
Applied Aquatic Ecology* \\
Aquatic Biogeochemistry* \\
Biogeochemical Processes and Global Changes* \\
Ecotoxicology* \\
Phytotechnologies \& Phytoremediation* \\
River Basin Processes and Dynamics \\
River Morphodynamics \\
Hydrogeology and Aquifer Management* \\
Modelling Marine and Coastal Processes* \\
Environmental Modelling and Statistics* \\
Hydrology and Climatology \\
Eutrophication Impacts in Marine Biodiversity \\
Wetlands \& Land-Water Ecotones* \\
Geosciences and River Training/Rehabilitation \\
Modelling Theory and Applications \\
Advanced Hydrological Modelling \\
Water Systems Modelling \\
Computational intelligence and control systems \\
Computational Hydraulics and information management \\
Information Technology and Software engineering \\
\hline Cross-Cutting Knowledge and Skills \\
International Environmental Law \\
Integrated Wetland Management* \\
Integrated Coastal Zone Management* \\
Integrated River Basin Management* \\
Environmental Protection Politics* \\
Ecosystem Protection \& Spatial Concepts to \\
Manage Natural Resources* \\
Techniques of marine intervention* \\
Environmental/Landscape Planning \\
\end{tabular}

years from supply-driven systems based on the discretion of academics to a more demand-driven model which better considers the needs of the workplace (Le Diest and Winterton, 2005). This paradigm shift applies to education in many disciplines, including other discipline areas in water resources (engineering, hydrogeosciences, etc.). In this section we consider approaches to develop these personal competencies.

Creativity and innovation are critical to the solution of current and future water related problems (Bernauer, 2002; van der Brugge and Rotmans, 2007). Creativity is, to a degree, an inherent attribute of a person, but creativity can also be stimulated. Creativity flows from people who are intrinsically motivated (e.g. they like what they are doing), and motivation can be fostered by assigning interesting and challenging tasks, ensuring a supportive attitude and frequent feedback from superiors, and fostering supportive interactions with fellow students or team members (Shalley et al., 2004). In an educational context, assignments should be designed to include high levels of personal responsibility, feedback, significance, and variety; and interactions with instructors and fellow students should encourage greater curiosity, cognitive flexibility, risk taking, and persistence in the face of barriers. All of these attributes serve to motivate in a manner that stimulates creativity (Shalley et al., 2004). Students who grow accustomed to working in this manner are likely to encourage these same attributes in their peers and seek out future collaborators with whom they have creative interactions.

Addressing knowledge needs for water resources management requires teams of scientists who cooperate to address a common problem. Organizations are also increasingly organizing staff into teams with focused objectives (Devine et al., 1999). Effective teamwork requires a high level of cooperation both to manage the team and improve its performance. Action regulation theory provides an effective framework for achieving high team performance by sequentially preparing, executing, evaluating, and adjusting team actions in relation to a given goal (Rousseau et al., 2006). Each of these stages requires specific behaviors by team members. Goal setting, planning, coordination, and information exchange are important cooperative skills to develop (Rousseau et al., 2006), as are backing-up behaviors and a collective belief that the team will succeed (Porter et al., 2011). Frameworks for teamwork should be introduced in the training of ecohydrologists and applied in group work activities within courses.

Effective communication skills (speaking, writing, and listening) are essential to the ecohydrologist both to communicate with colleagues as well as to communicate with stakeholders and the public at large. Basic scientific communication skills (Fig. 3) should ideally be taught from secondary school onward (Spektor-Levy et al., 2009), but depending on the cultural and educational background of students, these skills may need to be further developed. Skill development at the graduate level should include the full range of professional communication modalities and media. Communication in science and among scientists has evolved greatly since 


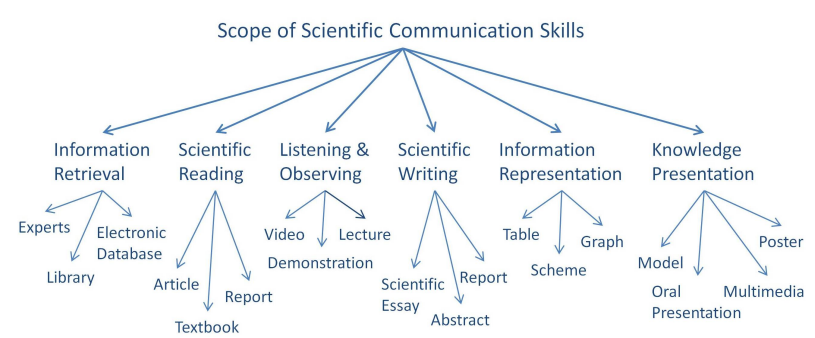

Fig. 3. Components of effective scientific communication. Redrawn from Spektor-Levy et al. (2009).

the days of the Garvey-Griffin Model, which described the traditional paper-based system of publications followed by indexing of abstracts and retrieval of bound journals from the library shelf for photocopying (Garvey and Griffin, 1972). The near paperless communication system of today is far more dynamic and interactive (Hurd, 2000), and the future impacts of a growing number of social media tools are only beginning to be studied (Arslan et al., 2011; Sublet et al., 2011). Because ecohydrologists deal with applied issues that often capture the interest of the general public, instruction should also be offered in speaking to general audiences and even writing in more popular styles. Training in these topics may be less formal and offered in seminars, workshops, or online tutorials in association with degree programs.

In this paper we have asserted that ecohydrologists are uniquely positioned to play a leading scientific role in addressing critical water-related issues such as rain-fed agriculture, surface and groundwater pollution, alterations to river flow regimes, and eutrophication. This assertion is based on the fact that water and the water cycle are at the center of complex biophysical and socioeconomic processes affecting these issues and, as we have seen, ecohydrologists should be trained to consider the trans-disciplinary nature of these problems and effectively work in teams to address them. A final important personal competency is therefore leadership, and leadership of teams in particular. Here we subscribe to Chemers' definition of leadership as "a process of social influence in which one person is able to enlist the aid and support of others in the accomplishment of a common task" (Chemers, 1997). Leadership in teams is both task-focused and person-focused, each of which may have a significant impact on team performance (Fleishman et al., 1991; Salas et al., 1992). The most important task-focused contribution of a leader is effective representation of the team to outside stakeholders and acquiring necessary resources. The most important behavior in person-focused leadership is empowerment, which comes through coaching, feedback, and monitoring (Burke et al., 2006). Basic training in these fundamental leadership skills should be made explicit in ecohydrology training programs and integrated into group activities.

\section{Conclusions}

Hydrology and ecology were born out of opposing intellectual worldviews: hydrology from the Newtonian perspective of simplifying the complexity of nature to essential functions and ecology from the Darwinian perspective of insisting on the complexity of nature and seeking patterns within it (Harte, 2002). The merger of these worldviews has come through the expansion and eventual overlapping of knowledge in both fields, and a growing awareness that the complex environmental problems facing the world must be addressed in an integrative and holistic manner. Ecohydrology as an applied science emerged from this mix. Now it is capitalizing on the strengths of its parent disciplines, stimulating new dialogue among hydrologists and ecologists, and forming its own identity in the pursuit of knowledge to address major environmental problems (Bond, 2003; Zalewski, 2011).

In this paper we have delineated three spheres of ecohydrology and presented our perspective on how educational programs might be formulated to support the continued growth of ecohydrology as a science and professional field. We highlight Master's training as the level at which ecohydrologists are best formed as professionals, recognizing that students may be introduced to ecohydrology in undergraduate courses, and a small proportion will continue to conduct cutting-edge research at the $\mathrm{PhD}$ level and take up academic positions. We have offered suggestions for a core curriculum of required and elective courses made up of subjects regularly offered in university curricula and enhanced by methodology courses (field, laboratory, and computer) and abundant group work. We avoid proposing a curriculum of entirely new, ecohydrology-specific courses, recognizing that ecohydrology is more likely to appear as a specialization taught in parallel with other specializations in hydrology or ecology programs rather than as a separate, standalone program. It is appropriate for the sub discipline to remain closely linked to these parent disciplines.

Finally, we encourage programs to emphasize the applied focus of ecohydrology from the beginning so that students understand that they are preparing to join in collaborative efforts to address specific environmental problems and promote improved water resources management. They therefore require $\mathrm{T}$-shaped competency profiles that include a depth of knowledge in the science of ecohydrology and a breadth of related professional and personal competencies. Toward this end programs should be structured in ways that help develop the personal skills of students, such as creativity, cooperation, communication, and leadership. These skills may be developed in the context of course work as well as through additional workshops, seminars, and trainings running parallel to the courses. 
Acknowledgements. Authors of this paper represent the consortium of institutions jointly offering the Erasmus Mundus Master of Science in Ecohydrology (www.ecohyd.org), financed by the European Commission. Partial financial support for the preparation of this paper was also provided by the Dutch Ministry of Foreign Affairs through the DUPC program at UNESCO-IHE.

Edited by: J. Seibert

\section{References}

Alber, M.: A conceptual model of estuarine freshwater inflow management, Estuaries, 25, 1246-1261, doi:10.1007/bf02692222, 2002.

Arslan, B. K., Boyd, E. S., Dolci, W. W., Dodson, K. E., Boldt, M. S., and Pilcher, C. B.: Workshops without Walls: Broadening Access to Science around the World, Plos Biology, 9, e1001118, doi:10.1371/journal.pbio.1001118, 2011.

Arthington, A. H., Naiman, R. J., McClain, M. E., and Nilsson, C.: Preserving the biodiversity and ecological services of rivers: new challenges and research opportunities, Freshwater Biol., 55, 116, doi:10.1111/j.1365-2427.2009.02340.x, 2010.

Asbjornsen, H., Goldsmith, G. R., Alvarado-Barrientos, M. S., Rebel, K., Van Osch, F. P., Rietkerk, M., Chen, J. Q., Gotsch, S., Tobon, C., Geissert, D. R., Gomez-Tagle, A., Vache, K., and Dawson, T. E.: Ecohydrological advances and applications in plant-water relations research: a review, J. Plant Ecol.-UK, 4, 322, 2011.

Bai, J., Chen, X., Li, J., Yang, L., and Fang, H.: Changes in the area of inland lakes in arid regions of central Asia during the past 30 years, Environ. Monit. Assess., 178, 247-256, 2011.

Bernauer, T.: Explaining success and failure in international river management, Aquat. Sci., 64, 1-19, doi:10.1007/s00027-0028050-4, 2002.

Bond, B.: Hydrology and ecology meet - and the meeting is good, Hydrol. Process., 17, 2087-2089, 2003.

Bornette, G., Amoros, C., and Lamouroux, N. L.: Aquatic plant diversity in riverine wetlands: The role of connectivity, Freshwater Biol., 39, 267-283, doi:10.1046/j.1365-2427.1998.00273.x, 1998.

Boulton, A. J., Datry, T., Kasahara, T., Mutz, M., and Stanford, J. A.: Ecology and management of the hyporheic zone: streamgroundwater interactions of running waters and their floodplains, J. N. Am. Benthol. Soc., 29, 26-40, 2010.

Brunke, M. and Gonser, T.: The ecological significance of exchange processes between rivers and groundwater, Freshwater Biol., 37 , 1-33, doi:10.1046/j.1365-2427.1997.00143.x, 1997.

Burgin, A. J. and Hamilton, S. K.: Have we overemphasized the role of denitrification in aquatic ecosystems? A review of nitrate removal pathways, Front. Ecol. Environ., 5, 89-96, doi:10.1890/1540-9295(2007)5[89:hwotro]2.0.co;2, 2007.

Burke, C. S., Stagl, K. C., Klein, C., Goodwin, G. F., Salas, E., and Halpin, S. M.: What type of leadership behaviors are functional in teams? A meta-analysis, Leadership Quart., 17, 288307, doi:10.1016/j.leaqua.2006.02.007, 2006.

Cash, D. W., Clark, W. C., Alcock, F., Dickson, N. M., Eckley, N., Guston, D. H., Jager, J., and Mitchell, R. B.: Knowledge systems for sustainable development, P. Natl. Acad. Sci. USA, 100, 80868091, doi:10.1073/pnas.1231332100, 2003.
Caylor, K. K., D'Odorico, P., and Rodriguez-Iturbe, I.: On the ecohydrology of structurally heterogeneous semiarid landscapes, Water Resour. Res., 42, W07424, doi:10.1029/2005wr004683, 2006.

Chemers, M. M.: An integrative theory of leadership, Lawrence Elrbaum Associates, Inc., Publishers, Mahwah, 1997.

Chícharo, L., Chícharo, M. A., and Ben-Hamadou, R.: Use of a hydrotechnical infrastructure (Alqueva Dam) to regulate planktonic assemblages in the Guadiana estuary: Basis for sustainable water and ecosystem services management, Estuar. Coastal Shelf S., 70, 3-18, 2006.

Cloern, J. E.: Our evolving conceptual model of the coastal eutrophication problem, Mar. Ecol.-Prog. Ser., 210, 223-253, doi:10.3354/meps210223, 2001.

Colman, E. A.: Vegetation and Watershed Management: An Appraisal of Vegetation Management in Relation to Water Supply, Flood Control, and Soil Erosion, Ronald Press Co., New York, 412 pp., 1953.

Costanza, R., d'Arge, R., de Groot, R., Farber, S., Grasso, M., Hannon, B., Limburg, K., Naeem, S., Oneill, R. V., Paruelo, J., Raskin, R. G., Sutton, P., and van den Belt, M.: The value of the world's ecosystem services and natural capital, Nature, 387, 253-260, doi:10.1038/387253a0, 1997.

Daugharty, D. A.: A new paradigm for education in the hydrological sciences, Can. Water Res. J., 16, 347-353, 1991.

Devine, D. J., Clayton, L. D., Philips, J. L., Dunford, B. B., and Melner, S. B.: Teams in organizations - Prevalence, characteristics, and effectiveness, Small Gr. Res., 30, 678-711, doi:10.1177/104649649903000602, 1999.

Dosskey, M. G.: Toward quantifying water pollution abatement in response to installing buffers on crop land, Environ. Manage., 28, 577-598, doi:10.1007/s002670010245, 2001.

Drinkwater, K. F. and Frank, K. T.: Effects of river regulation and diversion on marine fish and invertebrates, Aquat. Conserv., 4, 135-151, 1994.

Dudgeon, D., Arthington, A. H., Gessner, M. O., Kawabata, Z. I., Knowler, D. J., Leveque, C., Naiman, R. J., PrieurRichard, A. H., Soto, D., Stiassny, M. L. J., and Sullivan, C. A.: Freshwater biodiversity: importance, threats, status and conservation challenges, Biol. Rev., 81, 163-182, doi:10.1017/s1464793105006950, 2006.

Ellison, A. M.: An introduction to Bayesian inference for ecological research and environmental decision-making, Ecol. Appl., 6, 1036-1046, doi:10.2307/2269588, 1996.

Eshleman, K. N.: Hydrological consequences of land use change: A state-of-the-science review, in: Ecosystems and Land Use Change, edited by: DeFries, R. S., Asner, G. P., and Houghton, R. A., American Geophysical Union, Washington, DC, 13-30, 2004.

Falkenmark, M.: Water Management and Ecosystems: Living with Change, Stockholm, 2003.

Falkenmark, M. and Rockström, J.: Balancing Water for Humans and Nature: The New Approach in Ecohydrology, Earthscan, London, 2004.

Falkenmark, M. and Rockström, J.: The new blue and green water paradigm: Breaking new ground for water resources planning and management, J. Water Resour. Pl.-ASCE, 132, 129132, doi:10.1061/(asce)0733-9496(2006)132:3(129), 2006. 
Fleishman, E. A., Mumford, M. D., Zaccaro, S. J., Levin, K. Y., Korotkin, A. L., and Hein, M. B.: Taxonomic efforts in the description of leader behavior: A synthesis and functional interpretation, Leadership Quart., 2, 245-287, 1991.

Fohrer, N., Haverkamp, S., and Frede, H. G.: Assessment of the effects of land use patterns on hydrologic landscape functions: development of sustainable land use concepts for low mountain range areas, Hydrol. Process., 19, 659-672, doi:10.1002/hyp.5623, 2005.

Foley, J. A., DeFries, R., Asner, G. P., Barford, C., Bonan, G., Carpenter, S. R., Chapin, F. S., Coe, M. T., Daily, G. C., Gibbs, H. K., Helkowski, J. H., Holloway, T., Howard, E. A., Kucharik, C. J., Monfreda, C., Patz, J. A., Prentice, I. C., Ramankutty, N., and Snyder, P. K.: Global consequences of land use, Science, 309, 570-574, doi:10.1126/science.1111772, 2005.

Garvey, W. D. and Griffith, B. C.: Communication and information processing within scientific disciplines: Empirical findings for psychology, Inform. Storage Ret., 8, 123-126, 1972.

Gaviño Novillo, M.: Scenarios for environmental flow: The Atuel River and Wetlands case study (Argentina), National University of La Pampa, Santa Rosa, Argentina, 2005 (in Spanish).

Gillanders, B. M. and Kingsford, M. J.: Impact of changes in flow of freshwater on estuarine and open coastal habitats and the associated organisms, in: Oceanography and Marine Biology, Vol. 40, Oceanography and Marine Biology, Taylor \& Francis Ltd., London, 233-309, 2002.

Gillson, J.: Freshwater Flow and Fisheries Production in Estuarine and Coastal Systems: Where a Drop of Rain Is Not Lost, Rev. Fish. Sci., 19, 168-186, doi:10.1080/10641262.2011.560690, 2011.

GWP (Global Water Partnership): Integrated Water Resources Management, Global Water Partnership Technical Advisory Committee, Background Paper No.4, 67 pp., 2000.

Hannah, D. M., Sadler, J. P., and Wood, P. J.: Hydroecology and ecohydrology: a potential route forward?, Hydrol. Process., 21, 3385-3390, doi:10.1002/hyp.6888, 2007.

Harte, J.: Toward a synthesis of the Newtonian and Darwinian worldviews, Phys. Today, 55, 29-34, doi:10.1063/1.1522164, 2002.

Hill, N. M., Keddy, P. A., and Wisheu, I. C.: A hydrological model for predicting the effects of dams on the shoreline vegetation of lakes and reservoirs, Environ. Manage., 22, 723-736, doi:10.1007/s002679900142, 1998.

Hmelo-Silver, C. E.: Problem-based learning: What and how do students learn?, Educ. Psychol. Rev., 16, 235-266, doi:10.1023/B:EDPR.0000034022.16470.f3, 2004.

Hurd, J. M.: The transformation of scientific communication: A model for 2020, J. Am. Soc. Inform. Sci., 51, 1279-1283, doi:10.1002/1097-4571(2000)9999:9999;::aidasi1044i3.0.co;2-1, 2000.

IPCC: Climate Change 2007: Synthesis Report, IPCC, Geneva, 104 pp., 2007.

Katz, R. W., Parlange, M. B., and Naveau, P.: Statistics of extremes in hydrology, Adv. Water Resour., 25, 1287-1304, doi:10.1016/s0309-1708(02)00056-8, 2002.

Kimmerer, W. J.: Effects of freshwater flow on abundance of estuarine organisms: physical effects or trophic linkages?, Mar. Ecol.Prog. Ser., 243, 39-55, doi:10.3354/meps243039, 2002.
Klemes, V.: The science of hydrology: where have we been? where should we be going? what do hydrologists need to know?, International Symposium to Commemorate the 25 Years of IHD/IHP, Paris, 1991.

Kundzewicz, Z. W.: Ecohydrology - seeking consensus on interpretation of the notion, Hydrolog. Sci. J., 47, 799-804, doi:10.1080/02626660209492982, 2002.

Lake, P. S., Bond, N., and Reich, P.: Linking ecological theory with stream restoration, Freshwater Biol., 52, 597-615, doi:10.1111/j.1365-2427.2006.01709.x, 2007.

Lange, O. L., Kappen, L., and Schulze, E.-D.: Water and plant life: problems and modern approaches, Ecological Studies, Vol. 19, Springer-Verlag, New York, 536 pp., 1976.

Le Deist, F. O. D. and Winterton, J.: What Is Competence?, Human Resource Development International, 8, 27-46, 2005.

Leemans, R., Asrar, G., Busalacchi, A., Canadell, J., Ingram, J., Larigauderie, A., Mooney, H., Nobre, C., Patwardhan, A., Rice, M., Schmidt, F., Seitzinger, S., Virji, H., Vörösmarty, C., and Young, O.: Developing a common strategy for integrative global environmental change research and outreach: the Earth System Science Partnership (ESSP) Strategy paper, Current Opinion in Environmental Sustainability, 1, 4-13, doi:10.1016/j.cosust.2009.07.013, 2009.

Likens, G. E., Bormann, F. H., Pierce, R. S., Eaton, J. S., and Johnson, N. M.: Biogeochemistry of a Forested Ecosystem, SpringerVerlag, New York, 153 pp., 1977.

Livingston, R. J., Niu, X., Lewis, F. G., and Woodsum, G. C.: Freshwater Input to a Gulf Estuary: Long-Term Control of Trophic Organization, Ecol. Appl., 7, 277-299, 1997.

Lytle, D. A. and Poff, N. L.: Adaptation to natural flow regimes, Trends Ecol. Evol., 19, 94-100, doi:10.1016/j.tree.2003.10.002, 2004.

Marcarelli, A. M., Baxter, C. V., Mineau, M. M., and Hall, R. O.: Quantity and quality: unifying food web and ecosystem perspectives on the role of resource subsidies in freshwaters, Ecology, 92, 1215-1225, 2011.

McClain, M. E.: The ecohydrological approach as a tool for managing water quality in large South American rivers, in: Ecohydrology - Processes, Models and Case Studies, edited by: Harper, D., Zalewski, M., and Pacini, N., CABI, Oxfordshire, 207-222, 2008.

McClain, M. E., Boyer, E. W., Dent, C. L., Gergel, S. E., Grimm, N. B., Groffman, P. M., Hart, S. C., Harvey, J. W., Johnston, C. A., Mayorga, E., McDowell, W. H., and Pinay, G.: Biogeochemical hot spots and hot moments at the interface of terrestrial and aquatic ecosystems, Ecosystems, 6, 301-312, doi:10.1007/s10021-003-0161-9, 2003.

McDowall, R.: Diadromy, history and ecology: a question of scale, Hydrobiologia, 602, 5-14, 2008.

MEA (Millennium Ecosystem Assessment): Ecosystems and Human Well-being: Synthesis Island Press, Washington, DC, 2005.

Merton, R. K.: Sociological ambivalence and other essays, Free Press, New York, 1976.

Meybeck, M.: Global analysis of river systems: from Earth system controls to Anthropocene syndromes, Philos. Tr. Royal Soc. B, 358, 1935-1955, doi:10.1098/rstb.2003.1379, 2003.

Micklin, P. P.: Desiccation of the Aral Sea - a Water Management Disaster in the Soviet-Union, Science, 241, 1170-1175, doi:10.1126/science.241.4870.1170, 1988. 
Monteith, J. L.: Evaporation and environment, in: Symposium of the Society for Experimental Biology, The State and Movement of Water in Living Organisms, edited by: Fagg, G. E., Academic Press, New York, 205-234, 1965.

Nace, R.: General evolution of the concept of the hydrological cycle, in Three Centuries of Scientific Hydrology, UNESCO-World Meteorological Organization-International Association of Hydrological Sciences, Paris, 40-48, 1974.

Naiman, R. J. and Decamps, H.: The ecology of interfaces: Riparian zones, Annu. Rev. Ecol. Syst., 28, 621-658, doi:10.1146/annurev.ecolsys.28.1.621, 1997.

Naiman, R. J., Decamps, H., and Pollock, M.: The Role of Riparian Corridors in Maintaining Regional Biodiversity, Ecol. Appl., 3, 209-212, doi:10.2307/1941822, 1993.

Naiman, R. J., Latterell, J. J., Pettit, N. E., and Olden, J. D.: Flow variability and the biophysical vitality of river systems, C. R. Geosci., 340, 629-643, doi:10.1016/j.crte.2008.01.002, 2008.

Nash, J. E., Eagleson, P. S., Philip, J. R., and van der Molen, W. H.: The education of hydrologists, Hydrolog. Sci. J., 35, 597-607, 1990.

Nemani, R. R., Keeling, C. D., Hashimoto, H., Jolly, W. M., Piper, S. C., Tucker, C. J., Myneni, R. B., and Running, S. W.: ClimateDriven Increases in Global Terrestrial Net Primary Production from 1982 to 1999, Science, 300, 1560-1563, 2003.

Newman, B. D., Wilcox, B. P., Archer, S. R., Breshears, D. D., Dahm, C. N., Duffy, C. J., McDowell, N. G., Phillips, F. M., Scanlon, B. R., and Vivoni, E. R.: Ecohydrology of waterlimited environments: A scientific vision, Water Resour. Res., 42, W06302, doi:10.1029/2005wr004141, 2006.

Ngambeki, I., Thompson, S. E., Troch, P. A., Sivapalan, M., and Evangelou, D.: Engaging the students of today and preparing the catchment hydrologists of tomorrow: student-centered approaches in hydrology education, Hydrol. Earth Syst. Sci. Discuss., 9, 707-740, doi:10.5194/hessd-9-707-2012, 2012.

Osborne, T. M., Lawrence, D. M., Slingo, J. M., Challinor, A. J., and Wheeler, T. R.: Influence of vegetation on the local climate and hydrology in the tropics: sensitivity to soil parameters, Clim. Dynam., 23, 45-61, doi:10.1007/s00382-004-0421-1, 2004.

Pahl-Wostl, C., Craps, M., Dewulf, A., Mostert, E., Tabara, D., and Taillieu, T.: Social learning and water resources management, Ecol. Soc., 12, 5, available at: http://www.ecologyandsociety.org/ vol12/iss2/art5/, 2007.

Palmer, M. A.: Beyond infrastructure, Nature, 467, 534-535, 2010.

Pitman, A. J.: The evolution of, and revolution in, land surface schemes designed for climate models, Int. J. Climatol., 23, 479510, doi:10.1002/joc.893, 2003.

Poff, N. L. and Allan, J. D.: Functional-Organization of Stream Fish Assemblages in Relation to Hydrological Variability, Ecology, 76, 606-627, doi:10.2307/1941217, 1995.

Poff, N. L. and Zimmerman, J. K. H.: Ecological responses to altered flow regimes: a literature review to inform the science and management of environmental flows, Freshwater Biol., 55, 194205, doi:10.1111/j.1365-2427.2009.02272.x, 2010.

Poff, N. L., Allan, J. D., Bain, M. B., Karr, J. R., Prestegaard, K. L., Richter, B. D., Sparks, R. E., and Stromberg, J. C.: The natural flow regime, Bioscience, 47, 769-784, doi:10.2307/1313099, 1997.

Popp, A., Vogel, M., Blaum, N., and Jeltsch, F.: Scaling up ecohydrological processes: Role of surface water flow in water- limited landscapes, J. Geophys. Res.-Biogeo., 114, G04013, doi:10.1029/2008jg000910, 2009.

Porporato, A. and Rodriguez-Iturbe, I.: Ecohydrology - a challenging multidisciplinary research perspective, Hydrolog. Sci. J., 47, 811-821, doi:10.1080/02626660209492985, 2002.

Porter, C., Gogus, C. I., and Yu, R. C. F.: Does Backing Up Behavior Explain the Efficacy-Performance Relationship in Teams?, Small Gr. Res., 42, 458-474, doi:10.1177/1046496410390964, 2011.

Prescott, G. W.: Objectionable algae with reference to the killing of fish and other animals, Hydrobiologia, 1, 1-13, 1948.

Priestly, C. H. B. and Taylor, R. J.: On the assessment of surface heat flux and evaporation using large-scale parameters, Mon. Weather Rev., 100, 80-91, 1972.

Richter, B. D., Baumgartner, J. V., Wigington, R., and Braun, D. P.: How much water does a river need?, Freshwater Biol., 37, 231249, doi:10.1046/j.1365-2427.1997.00153.x, 1997.

Rickwood, C., Hes, E., Al-Zu'bi, Y., and Dubé, M.: Overview of limitations, and proposals for improvement, in education and capacity building of Ecohydrology, Ecohydrology Hydrobiology, 10, 45-59, 2010.

Rietkerk, M., Boerlijst, M. C., van Langevelde, F., HilleRisLambers, R., van de Koppel, J., Kumar, L., Prins, H. H. T., and de Roos, A. M.: Self-organization of vegetation in arid ecosystems, Am. Nat., 160, 524-530, doi:10.1086/342078, 2002.

Robins, J. B., Halliday, I. A., Staunton-Smith, J., Mayer, D. G., and Sellin, M. J.: Freshwater-flow requirements of estuarine fisheries in tropical Australia: a review of the state of knowledge and application of a suggested approach, Mar. Freshwater Res., 56, 343-360, doi:10.1071/mf04087, 2005.

Rockström, J., Falkenmark, M., Karlberg, L., Hoff, H., Rost, S., and Gerten, D.: Future water availability for global food production: The potential of green water for increasing resilience to global change, Water Resour. Res., 45, W00A12, doi:10.1029/2007wr006767, 2009.

Rodriguez-Iturbe, I.: Ecohydrology: A hydrologic perspective of climate-soil-vegetation dynamics, Water Resour. Res., 36, 3-9, doi:10.1029/1999wr900210, 2000.

Rodriguez-Iturbe, I., D’Odorico, P., Laio, F., Ridolfi, L., and Tamea, S.: Challenges in humid land ecohydrology: Interactions of water table and unsaturated zone with climate, soil, and vegetation, Water Resour. Res., 43, doi:10.1029/2007wr006073, 2007.

Rousseau, V., Aube, C., and Savoie, A.: Teamwork behaviors - A review and an integration of frameworks, Small Gr. Res., 37, 540-570, doi:10.1177/1046496406293125, 2006.

Saito, L., Walker, M., Chandra, S., Miller, W. W., and Tyler, S.: Ecohydrology as an undergraduate degree: challenges in developing an interdisciplinary major, J. College Science Teaching, 38, 4045, 2009.

Salas, E., Dickinson, T. L., Converse, S. A., and Tannenbaum, S. I.: Toward an understanding of team performance and training, in: Teams: Their Training and Performance, edited by: Swezey, R. W. and Salas, E., ABLEX, Norwood, 3-29, 1992.

Seitzinger, S. P., Styles, R. V., Boyer, E. W., Alexander, R. B., Billen, G., Howarth, R. W., Mayer, B., and Van Breemen, N.: Nitrogen retention in rivers: model development and application to watersheds in the northeastern USA, Biogeochemistry, 57, 199237, doi:10.1023/a:1015745629794, 2002.

Shalley, C. E., Zhou, J., and Oldham, G. R.: The effects of personal and contextual characteristics on creativity: 
Where should we go from here?, J. Manage., 30, 933-958, doi:10.1016/j.jm.2004.06.007, 2004.

Smith, V.: Eutrophication of freshwater and coastal marine ecosystems a global problem, Environ. Sci. Pollut. R., 10, 126-139, 2003.

Spektor-Levy, O., Eylon, B. S., and Scherz, Z.: Teaching Scientific Communication Skills in Science Studies: Does It Make a Difference?, International Journal of Science and Mathematics Education, 7, 875-903, 2009.

Steffen, W., Crutzen, P. J., and McNeill, J. R.: The Anthropocene: Are humans now overwhelming the great forces of nature, Ambio, 36, 614-621, doi:10.1579/00447447(2007)36[614:taahno]2.0.co;2, 2007.

Sublet, V., Spring, C., and Howard, J.: Does Social Media Improve Communication? Evaluating the NIOSH Science Blog, Am. J. Ind. Med., 54, 384-394, doi:10.1002/ajim.20921, 2011.

Sun, T., Yang, Z. F., and Cui, B. S.: Critical Environmental Flows to Support Integrated Ecological Objectives for the Yellow River Estuary, China, Water Resour. Manag., 22, 973-989, 2008.

Tockner, K. and Stanford, J. A.: Riverine flood plains: present state and future trends, Environ. Conserv., 29, 308-330, doi:10.1017/s037689290200022x, 2002.

Uhlenbrook, S. and de Jong, E.: T-shaped competency profile for water professionals of the future, Hydrol. Earth Syst. Sci. Discuss., 9, 2935-2957, doi:10.5194/hessd-9-2935-2012, 2012.

UNESCO/ICSU (United Nations Educational and Cultural Organization/International Council of Scientific Unions): Declaration on Science and the Use of Scientific Knowledge, World Conference on Science for the Twenty-First Century: a New Commitment, Budapest, Hungary, 1999.

Vadeboncoeur, Y., Jeppesen, E., Vander Zanden, M. J., Schierup, H. H., Christoffersen, K., and Lodge, D. M.: From Greenland to green lakes: Cultural eutrophication and the loss of benthic pathways in lakes, Limnol. Oceanogr., 48, 1408-1418, 2003.

van der Brugge, R. and Rotmans, J.: Towards transition management of European water resources, Water Resour. Manag., 21, 249-267, doi:10.1007/s11269-006-9052-0, 2007.

van Griensven, A., Meixner, T., Grunwald, S., Bishop, T., Diluzio, A., and Srinivasan, R.: A global sensitivity analysis tool for the parameters of multi-variable catchment models, J. Hydrol., 324, 10-23, doi:10.1016/j.jhydrol.2005.09.008, 2006.

Vitousek, P. M., Mooney, H. A., Lubchenco, J., and Melillo, J. M.: Human domination of Earth's ecosystems, Science, 277, 494499, doi:10.1126/science.277.5325.494, 1997.

Vörösmarty, C. J., McIntyre, P. B., Gessner, M. O., Dudgeon, D., Prusevich, A., Green, P., Glidden, S., Bunn, S. E., Sullivan, C. A., Liermann, C. R., and Davies, P. M.: Global threats to human water security and river biodiversity, Nature, 467, 555-561, doi:10.1038/nature09440, 2010.

Volker, A. and Colenbrander, H.: History of the International Association of Hydrological Sciences, available at: http://iahs.info/ history/history.htm (last access: 22 June 2012), 2009.

Wagener, T., Sivapalan, M., Troch, P. A., McGlynn, B. L., Harman, C. J., Gupta, H. V., Kumar, P., Rao, P. S. C., Basu, N. B., and Wilson, J. S.: The future of hydrology: An evolving science for a changing world, Water Resour. Res., 46, W05301, doi:10.1029/2009wr008906, 2010.
Wagener, T., Kelleher, C., Weiler, M., McGlynn, B., Gooseff, M., Marshall, L., Meixner, T., McGuire, K., Gregg, S., Sharma, P., and Zappe, S.: It takes a community to raise a hydrologist: the Modular Curriculum for Hydrologic Advancement (MOCHA), Hydrol. Earth Syst. Sci. Discuss., 9, 2321-2356, doi:10.5194/hessd-9-2321-2012, 2012.

Wagner, I. and Zalewski, M.: Ecohydrology as a basis for the sustainable city strategic planning: focus on Lodz, Poland, Reviews in Environmental Science and Biotechnology, 8, 209-217, 2009.

Ward, J. V., Tockner, K., Uehlinger, U., and Malard, F.: Understanding natural patterns and processes in river corridors as the basis for effective river restoration, Regul. River., online first: doi:10.1002/rrr.646.abs, 2001.

Wilcox, B. P.: Transformative ecosystem change and ecohydrology: ushering in a new era for watershed management, Ecohydrology, 3, 126-130, doi:10.1002/eco.104, 2010.

Willis, S. C., Jones, A., Bundy, C., Burdett, K., Whitehouse, C. R., and O'Neill, P. A.: Small-group work and assessment in a PBL curriculum: a qualitative and quantitative evaluation of student perceptions of the process of working in small groups and its assessment, Med. Teach., 24, 495-501, doi:10.1080/0142159021000012531, 2002.

Wohl, E., Angermeier, P. L., Bledsoe, B., Kondolf, G. M., MacDonnell, L., Merritt, D. M., Palmer, M. A., Poff, N. L., and Tarboton, D.: River restoration, Water Resour. Res., 41, doi:10.1029/2005wr003985, 2005.

Wolanski, E., Boorman, L. A., Chícharo, L., Langlois-Saliou, E., Lara, R., Plater, A. J., Uncles, R. J., and Zalewski, M.: Ecohydrology as a new tool for sustainable management of estuaries and coastal waters, Wetl. Ecol. Manag., 12, 235-276, 2004.

Wondzell, S. M.: The role of the hyporheic zone across stream networks, Hydrol. Process., 25, 3525-3532, doi:10.1002/hyp.8119, 2011.

Zalewski, M.: Ecohydrology - the scientific background to use ecosystem properties as management tools toward sustainability of water resources, Ecol. Eng., 16, 1-8, doi:10.1016/s09258574(00)00071-9, 2000.

Zalewski, M.: Ecohydrology - the use of ecological and hydrological processes for sustainable management of water resources, Hydrolog. Sci. J., 47, 823-832, doi:10.1080/02626660209492986, 2002.

Zalewski, M.: Ecohydrology for implementation of the EU water framework directive, P. I. Civil Eng.-Wat. M., 164, 375-385, doi:10.1680/wama.1000030, 2011.

Zalewski, M., Janauer, G. S., and Jolankai, G. (Eds.): Ecohydrology - A New Paradigm for the Sustainable Use of Aquatic Resources, UNESCO IHP-V, Technical document in Hydrology No. 7, 1997.

Zalewski, M., Harper, D. M., Demars, B., Jolánkai, G., Crosa, G., Janauer, G. A., and Pacini, N.: Linking biological and physical processes at the river basin scale: the origins, scientific background and scope of ecohydrology, in: Ecohydrology - Processes, Models and Case Studies, edited by: Harper, D., Zalewski, M., and Pacini, N., CABI, Oxfordshire, 1-17, 2008.

Zedler, J. B.: Progress in wetland restoration ecology, Trends Ecol. Evol., 15, 402-407, doi:10.1016/s0169-5347(00)01959-5, 2000. 